\title{
Negative Effects of Late Bronze Age Human Activity on Modern Soils and Landscapes, a Case-study on the Muradymovo Settlement, Urals, Russia
}

\author{
Alexandra Golyeva ${ }^{a^{*}}$, Olga Khokhlova ${ }^{\mathrm{b}}$, Nikolai Shcherbakov ${ }^{\mathrm{c}}$, Iia Shuteleva ${ }^{\mathrm{c}}$ \\ ${ }^{a}$ Institute of Geography, Russian Academy of Sciences, Staromonetniy pereulok 29, 119017 Moscow, Russia \\ ${ }^{b}$ Institute of Physicochemical and Biological Problems of Soil Science-Pushchino Scientific Centre, Russian Academy of Sciences, 142290 Pushchino, \\ Moscow Region, Russia \\ ${ }^{c}$ Archaeological Laboratory of Bashkir State Pedagogical University, Oktyabrskoy Revolutsii street 3a, Ufa, Bashkortostan, Russia
}

\section{ARTICTLE INFO}

\section{Article history:}

Received: $23^{\text {rd }}$ March 2016

Accepted: $28^{\text {th }}$ December 2016

\section{Key words:}

ancient settlement

modern soil

properties

gypsum

transformation rate

\section{Introduction}

Pedological studies on archaeological sites can often help to reconstruct the palaeoenvironment of an archaeological monument's functioning period (Weiss, Courty 1993; Redman 1999; Vrydaghs, Devos 2007; Zielinski et al. 2011; Sánchez-Pérez et al. 2013 and many others). This allows archaeologists to better understand the life-styles and economic activities of the ancient people and their interactions with the palaeoenvironment (Engovatova, Golyeva 2012; Jankowski, Kittel 2012; Goldie 2013; Markiewicz et al. 2013).

In some cases, the human impact on ancient landscapes has been so profound that local soils still remain significantly affected even after hundreds and thousands of years (Bettis 1988; Lima et al. 2002). There are no natural soils left within such sites, being replaced by completely different

*Corresponding author. E-mail: golyevaaa@yandex.ru anthropogenic soils with specific properties (Woods, McCann 1999; Nicocia et al. 2011; Antisari et al. 2013; Pawłowski et al. 2015; Thy et al. 2015).

Studying the causes and implications of such negative influences of past human activities on soils and the environment is necessary to prevent similar accidents in the future. We believe this is an important research area at the present time, when anthropogenic pressures on the environment are increasing.

The present article describes a case-study of the extremely severe and long-lasting impact of ancient people on their soils and environment. The study site is the Late Bronze Age settlement of Muradymovo located in the Bashkortostan Republic (Urals region, Russia). The site and its area have a peculiar "hillocky" microrelief that does not occur anywhere else in the Bashkortostan Republic. The local residents assumed that the hillocks were old tree stumps overgrown with grass, but we suggested that they were traces of ancient human activity. According to the archaeological 
data (Shcherbakov et al. 2013; Shcharbakov et al. 2015), the Muradymovo people belonged to the "Srubno-Alakul" culture of the Late Bronze Age and came here from an extra arid semidesert region of the southern Kazakhstan, where they used to build their houses of gypsum rock. There is a deposit of gypsum rock just $5 \mathrm{~km}$ away from the Muradymovo settlement site.

Gypsum is an excellent construction material in the driest parts of arid regions, for example, within depressions that remain from former inland lakes or seas (Rosen, Warren 1990; Bolen et al. 1991). However, in humid climates gypsum is soluble and houses made of it undergo rapid degradation. The residual piles of gypsum rock account for the appearance of the aforementioned hillocky microrelief of the study site (Slavnyi 2003). A similar microrelief typically occurs in deserts (Gorbunova 1977; Watson 1985; Eckardt et.al. 2001; Warren 2006), but would not be expected to be found in this humid region of Urals. In addition, the ancient settlement site Muradymovo is located on a hill, and not within a depression.

The aim of our study was to investigate the properties of modern soils at the Bronze Age settlement site and understand more about the factors that led to their formation and transformation.

\section{Materials and methods}

\subsection{Materials}

\subsubsection{Location and natural conditions at the site}

The study site $\left(53^{\circ} 58^{\prime} 44.8^{\prime \prime} \mathrm{N}, 55^{\circ} 30^{\prime} 58.8^{\prime \prime} \mathrm{E}\right)$ is located $2.5 \mathrm{~km}$ north of the village of Muradymovo, in the Aurgazinskiy District of the Bashkortostan Republic of Russia (Figure 1.1-2). The site of the Muradymovo ancient settlement with a total area of 6 ha is found within the Kamsko-Belsky Depression with generally a levelled topography resulting from denudation processes, on the first terrace of the right bank of the Urshak River, $0.2 \mathrm{~km}$ east of the mainstream, on a hill about 1.5-2 m high (Figure 1.4). The bedrock is composed of gypsum, anhydrite, dolomite and sandstone of the Kungur stage of the Permian Period. The bedrock is overlain by loess-like silty sediments of the Quaternary Period that serve as parent rocks for the soils.

The climate is continental, moderately cold. The mean annual air temperature is $+2.5^{\circ} \mathrm{C}$, the mean temperatures of January and July being $-15^{\circ} \mathrm{C}$ and $+19.5^{\circ} \mathrm{C}$, respectively. The frost-free period lasts 140 days, being the longest within the Bashkortostan Republic. The mean annual precipitation is about $500 \mathrm{~mm}$, with more than $300 \mathrm{~mm}$ falling during the growing season. The hydrothermal coefficient is about 1 (Atlas of the Bashkortostan Republic, 2005).

The typical modern vegetation is represented by steppe communities.

The typical soils are Greyzemic Chernozems (WRB, 2014) that are naturally gypsum-free to a depth of 2 metres (Bogomolov 1954; Khaziev 2007).

\subsubsection{Archaeology}

According to the archaeological data (Obydennova et al. 2008; Shuteleva et al. 2010), the settlement was built by ancient people of the "Srubno-Alakul" archaeological culture of the Late Bronze Age (1750-1350 BC cal), who lived here for no longer than 200-300 years. Later the settlement remained abandoned. At present, the site is covered with sparse steppe vegetation, partially used as a pasture and bordered by a gully from the west and north. There are six depressions (house pits) with areas from 260 to $300 \mathrm{~m}^{2}$ and depths from 0.25 to $0.4 \mathrm{~m}$ recorded within the site.

We studied two pits (houses III and IV) with the most representative morphology of cultural layers (Figures 2.2 and 2.3). Their past uses were different: pit III was a farm building whereas pit IV was an inhabited house. The distance between the pits was no more than $50 \mathrm{~m}$ (Figure 1.3). Pit III contained the remains of a farm building constructed on a single occasion and used for keeping cattle, as was indicated by the archaeological finds. Pit IV included several layers of house remains (no less than 5) and a hearth, i.e. this residential house had been rebuilt several times.

Two background soils outcropping from the banks of a small river opposite to each other at a short distance from the archaeological excavation site were also studied. These soils were least affected by the ancient settlement construction. The first soil profile (background soil 1) was on the same river bank as the settlement and contained a white-coloured lens between the surface horizon and the humus horizon (Figure 2.1.1). The other profile (background soil 2) was on the opposite bank and had no traces of ancient human impact, such as a white lens near the surface of the first profile (Figure 2.1.2).

The modern microrelief consists of small hillocks separated by deep frost cracks, which cover the whole area of the study site and beyond, up to the banks of the river and gully. Frost cracks have resulted from the recent influence of the continental climate. The hillocks are about $50 \mathrm{~cm}$ high and 1.5-2.2 m long (Figure 1.4). Such a peculiar microrelief is absent on the other side of the gully.

\subsection{Methods}

Our study was designed to describe the morphological characteristics of the pits and profiles in the field (according to archaeological standards) and to conduct chemical analyses of the samples in the laboratory using conventional techniques (Arinushkina 1970; Vorobiova 1998; 2006). We collected samples in vertical columns from all pits and profiles studied. The samples were dried and prepared according to the requirements for each specific analysis.

\subsubsection{Total phosphorus}

We determined the total phosphorus $\left(\mathrm{P}_{\text {tot }}\right)$, as we agree with Holliday and Gartner (2007) that $\mathrm{P}_{\text {tot }}$ "seems to be the best indicator of human activity". The procedure included sample combustion with concentrated sulfuric acid. Phosphate in the extract was determined calorimetrically using a SPECOL 

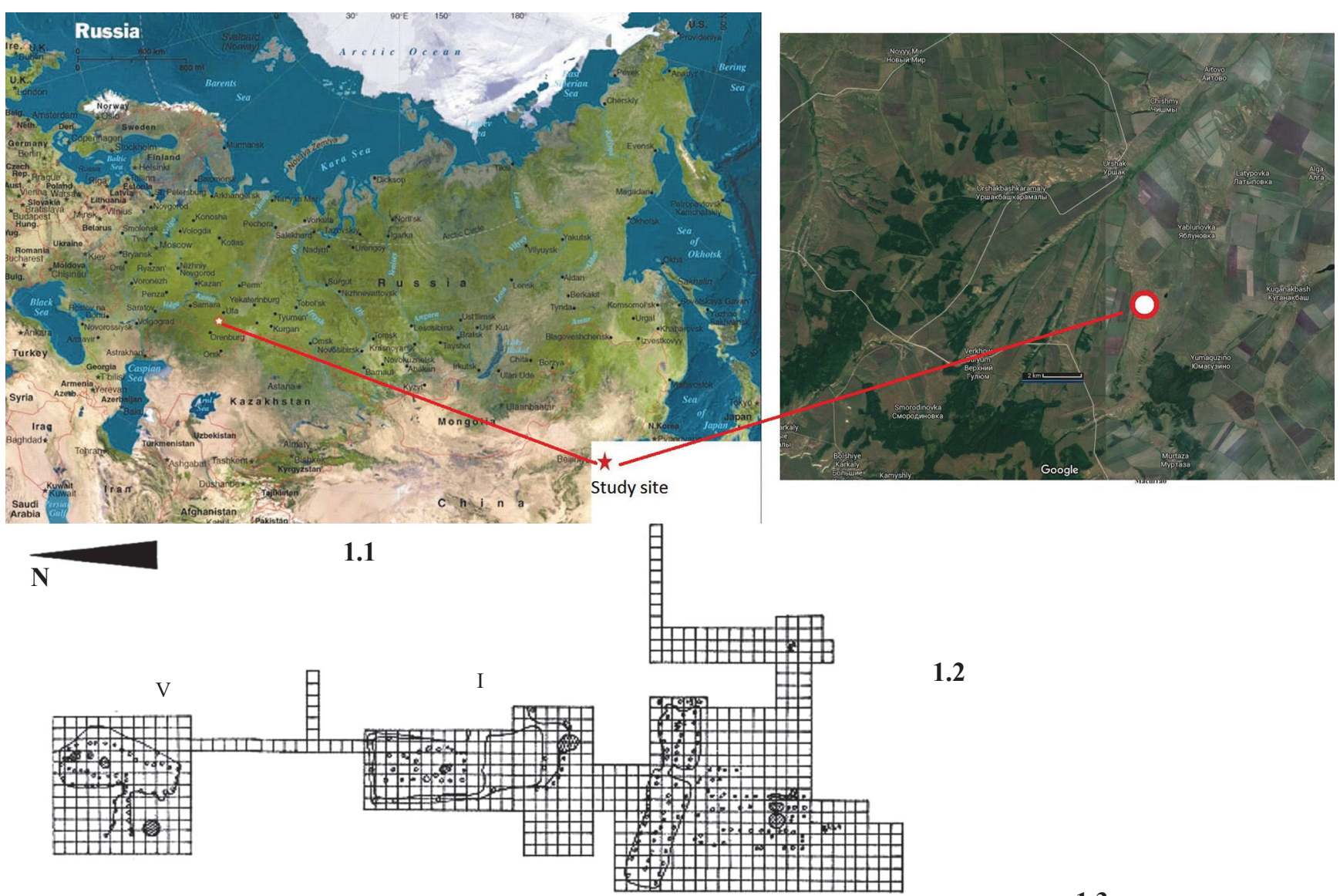

1.2

II

IV

$0 \quad \mathbf{n}^{16 \mathrm{~m}}$

III
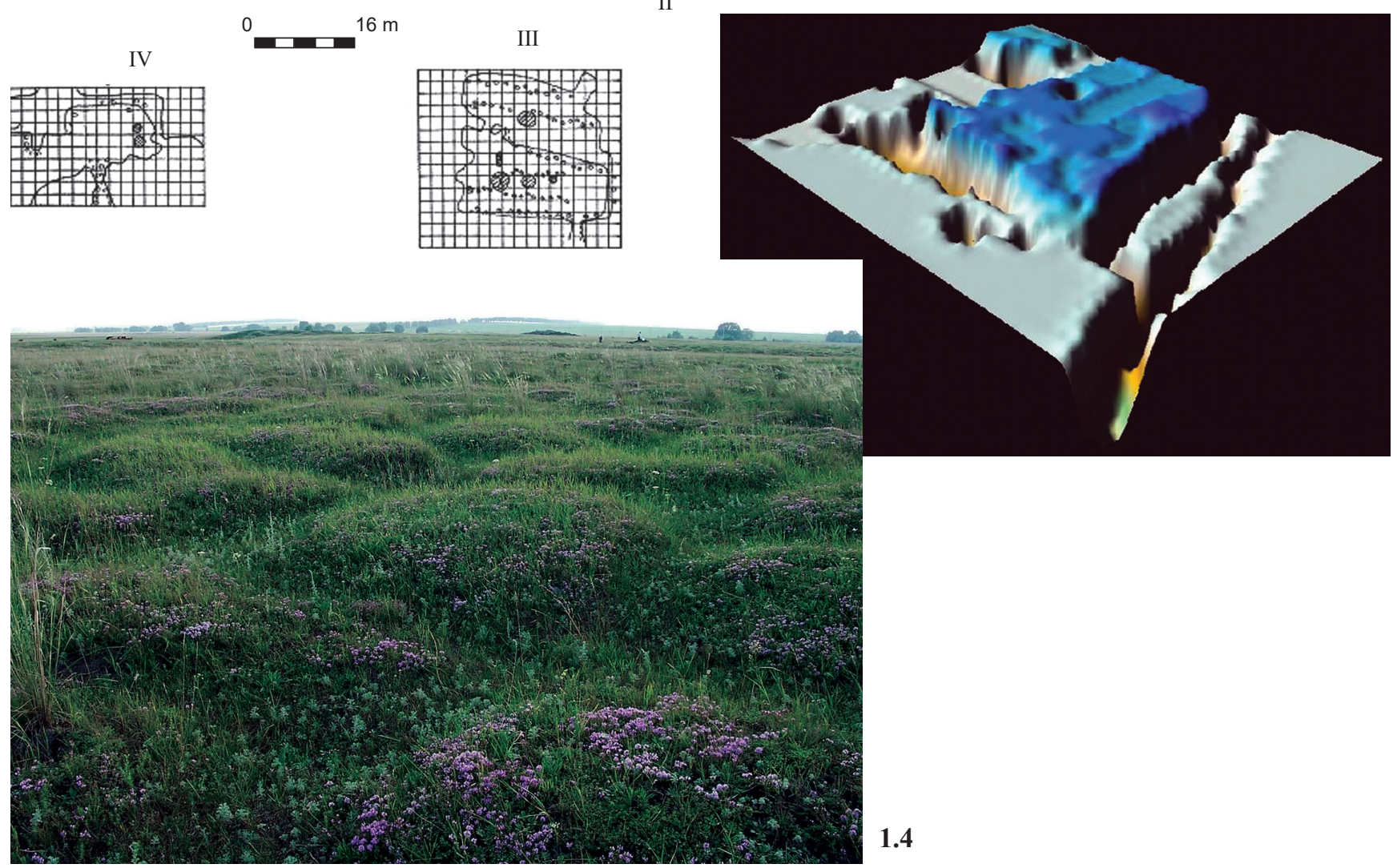

1.4

Figure 1. Study site locations: 1.1 Map of Russia with location of Muradymovo settlement (star) and areal map (Google) of Volga-Ural area with location of Muradymovo settlement (red ring). 1.2 Plan of the settlement area with excavated pits. 1.3 3D-reconstruction landscape of Muradymovo settlement by Golden Surfer Programme 9.0 Version. 1.4 Specific micro-relief on the surface of ancient settlement. 

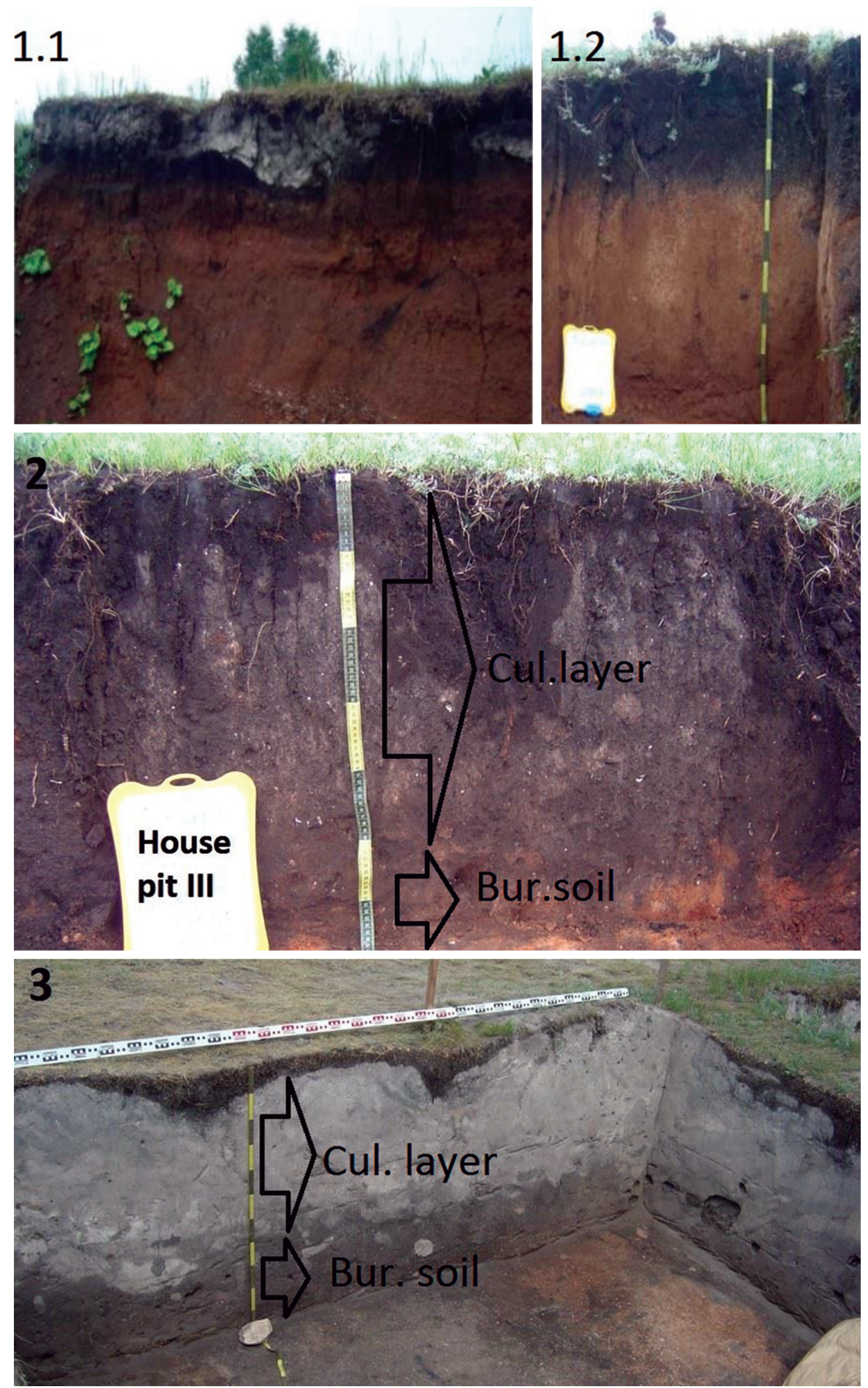

Figure 2. Soil profiles: 1.1 - Background soil 1 with gypsum lens on the surface. 1.2 - Background soil 2 without gypsum. 2 - Excavation pit III. 3 Excavation pit IV. The thickness of cultural layers and burial soils are shown on both excavation pits. 
211 spectrophotometer and a blue ammonium molybdate method with ascorbic acid as a reducing agent (Vorobiova, 1998; 2006).

\subsubsection{Gypsum}

Gypsum was determined using $10 \% \quad \mathrm{BaCl}_{2}$ solution (Arinushkina 1970). Each sample was boiled for 3 minutes in $0.2 \mathrm{~N} \mathrm{HCl}$, cooled for 30 minutes and passed through a filter. The filtrate was diluted with distilled water and passed through $\mathrm{H}$-cationite. The resulting solution was titrated with $\mathrm{BaCl}_{2}$ solution. The obtained values of $\mathrm{SO}_{4}$ concentrations were recalculated for gypsum $\left(\mathrm{CaSO}_{4} \times 2 \mathrm{H}_{2} \mathrm{O}\right)$.

\subsubsection{Water $\mathrm{pH}$}

Water $\mathrm{pH}\left(\mathrm{pH}_{\mathrm{H}_{2} \mathrm{O}}\right)$ was determined using a potentiometer, in suspension with soil to water ratio of 1:2.5, after a single shaking followed by settling for $30 \mathrm{~min}$ (Arinushkina 1970).

\subsubsection{Organic carbon}

The organic carbon was determined by the Tyurin method, which included the wet combustion of organic substance in a mixture of $0.4 \mathrm{~N} \mathrm{~K}_{2} \mathrm{Cr}_{2} \mathrm{O}_{7}$ and concentrated $\mathrm{H}_{2} \mathrm{SO}_{4}(1: 1)$ at $150^{\circ} \mathrm{C}$ for $20 \mathrm{~min}$. The measurements were performed by photometry on a SPECOL 211 spectrometer at $590 \mathrm{~nm}$ (Arinushkina 1970).

\subsubsection{Calcium carbonate}

Calcium carbonate concentrations in the samples were determined by alkalimetry using the Kozlovskii procedure. A soil sample was treated with $2 \mathrm{M} \mathrm{HCl}$; the released $\mathrm{CO}_{2}$ was absorbed by a $0.4 \mathrm{M} \mathrm{NaOH}$ solution. Then a saturated $\mathrm{BaCl}_{2}$ solution was added to the tube with $\mathrm{NaOH}$, and the excess of alkali was titrated with $0.2 \mathrm{M} \mathrm{HCl}$ (Vorobiova 1998; 2006). The obtained values of the carbonate ion concentrations were recalculated for calcium carbonates.

\section{Results}

\subsection{Morphological description}

The soils studied were considerably different from each other (Figure 2).

The background soil 1 had a light-coloured lens from 5 to $20 \mathrm{~cm}$ thick, containing powdery gypsum and no artefacts. The lens occurred between the surface litter and the humus horizon. All other morphological characteristics of background soil 1 were typical for Chernozems: high content of organic carbon and the secondary calcic horizon under the mollic horizon.

The background soil 2 had features of typical Chernozem, with the organic horizon thicker than $25 \mathrm{~cm}$, underlain by the calcic horizon.

Soil of excavation pit IV had an 80-cm-thick, lightcoloured surface layer containing diffuse secondary calcium sulfate and abundant artefacts - pottery, bones and charcoal (Shuteleva et al. 2010). This layer was underlain by buried Chernozem.

Soil of excavation pit III had a dark organic surface horizon, gypsum free. There were numerous artefacts within the upper $60 \mathrm{~cm}$ of this soil.

\subsection{Chemical analyses}

The results of chemical analyses are presented in Table 1 .

\subsubsection{Background soils}

Both background soils are alkaline throughout the profile and strongly alkaline at the bottom. Alkalinity of the lower layers is generally typical and connected with the presence of calcium carbonate, but the alkalinity of the uppermost part of the soil profile is atypical.

The organic carbon content and distribution are typical for Greyzemic Chernozems (IUSS Working Group WRB,

Table 1. Chemical properties of soils and cultural layers.

\begin{tabular}{cccccc}
\hline Depth, cm & $\mathbf{p H}_{\mathbf{H} 2 \mathbf{O}}$ & $\mathbf{C o r g}, \boldsymbol{\%}$ & $\mathbf{P}$ tot, $\%$, & $\mathbf{C a C O}_{\mathbf{3}}, \mathbf{\%}$ & $\mathbf{C a S O}_{\mathbf{4}}, \mathbf{\%}$ (gypsum) \\
\hline \multicolumn{5}{c}{ Pit IV, inhabited house } \\
\hline $0-5$ & 7.90 & 14.38 & 0.48 & 3.4 & 0.7 \\
$5-10$ & 8.25 & 11.37 & 0.64 & 15.3 & 1.9 \\
$10-20$ & 8.25 & 3.83 & 0.26 & 9.5 & 49.8 \\
$20-30$ & 8.20 & 2.65 & 0.29 & 13.6 & 49.9 \\
$30-40$ & 8.15 & 2.91 & 0.42 & 15.3 & 39.2 \\
$40-50$ & 8.20 & 2.31 & 0.50 & 14.4 & 38.2 \\
$50-60$ & 8.00 & 2.67 & 0.48 & 19.4 & 8.0 \\
$60-70$ & 7.90 & 2.18 & 0.48 & 15.9 & 31.4 \\
$70-80$ & 7.90 & 1.54 & 0.45 & 18.4 & 25.6 \\
$80-86$ & 8.00 & 2.06 & 0.38 & 24.6 & 3.9 \\
$86-96$ & 8.40 & 2.38 & 0.21 & 33.1 & 1.3 \\
$96-106$ & 8.60 & 1.79 & 0.19 & 38.3 & 2.7 \\
$106-116$ & 9.10 & 1.59 & 0.19 & 42.2 & 2.3 \\
\hline
\end{tabular}


Table 1. Chemical properties of soils and cultural layers. (Continuation)

\begin{tabular}{|c|c|c|c|c|c|}
\hline Depth, cm & $\mathrm{pH}_{\mathrm{H} 2 \mathrm{O}}$ & Corg, \% & P tot, $\%$, & $\mathrm{CaCO}_{3}, \%$ & $\mathrm{CaSO}_{4}, \%$ (gypsum) \\
\hline \multicolumn{6}{|c|}{ Pit III, farm building } \\
\hline $0-8$ & 8.30 & 7.31 & 0.29 & 12.7 & 0.07 \\
\hline $10-20$ & 8.70 & 5.67 & 0.31 & 16.9 & 0.09 \\
\hline $20-30$ & 8.95 & 4.83 & 0.31 & 20.3 & 0.16 \\
\hline $30-40$ & 9.00 & 3.39 & 0.30 & 24.4 & 0.18 \\
\hline $40-50$ & 9.10 & 3.22 & 0.34 & 25.8 & 0.18 \\
\hline $50-60$ & 9.25 & 2.22 & 0.25 & 30.1 & 0.09 \\
\hline $60-70$ & 9.20 & 0.41 & 0.13 & 37.4 & 0.39 \\
\hline \multicolumn{6}{|c|}{ Background soil 1} \\
\hline $0-10$ & 8.00 & 8.25 & 0.22 & 3.7 & 1.5 \\
\hline $10-20$ & 8.10 & 5.84 & 0.16 & 1.5 & 20.8 \\
\hline $20-30$ & 7.85 & 3.75 & 0.14 & 0.3 & 5.1 \\
\hline $30-40$ & 8.15 & 2.41 & 0.09 & 1.7 & 4.8 \\
\hline $40-50$ & 8.30 & 0.83 & 0.09 & 5.3 & 3.9 \\
\hline $50-60$ & 8.55 & 0.45 & 0.07 & 13.1 & 2.1 \\
\hline $60-70$ & 8.90 & 0.35 & 0.07 & 18.9 & 0.8 \\
\hline $70-80$ & 8.85 & 0.20 & 0.07 & 21.0 & 0.7 \\
\hline $80-90$ & 8.95 & 0.18 & 0.07 & 20.9 & 0.2 \\
\hline $90-100$ & 9.00 & 0.14 & 0.07 & 20.3 & 0.0 \\
\hline $100-110$ & 8.80 & - & 0.07 & 21.6 & 0.0 \\
\hline $110-120$ & 8.90 & - & 0.08 & 21.3 & 0.3 \\
\hline $120-130$ & 9.00 & - & 0.08 & 23.5 & 0.3 \\
\hline $130-140$ & 9.00 & - & 0.08 & 23.3 & 0.3 \\
\hline $140-150$ & 9.00 & - & 0.08 & 22.2 & 0.4 \\
\hline \multicolumn{6}{|c|}{ Background soil 2} \\
\hline $0-10$ & 7.35 & 12.72 & 0.21 & 3.4 & 0.0 \\
\hline $10-20$ & 7.95 & 5.36 & 0.17 & 1.7 & 0.0 \\
\hline $20-30$ & 8.15 & 4.65 & 0.15 & 0.0 & 0.0 \\
\hline $30-40$ & 8.15 & 3.07 & 0.10 & 0.0 & 0.0 \\
\hline $40-50$ & 8.25 & 2.19 & 0.08 & 1.8 & 0.0 \\
\hline $50-60$ & 8.30 & 2.47 & 0.08 & 4.5 & 0.0 \\
\hline $60-70$ & 8.30 & 1.19 & 0.07 & 9.3 & 0.0 \\
\hline $70-80$ & 8.15 & 0.88 & 0.07 & 15.7 & 0.0 \\
\hline $80-90$ & 8.15 & 0.45 & 0.07 & 18.6 & 0.2 \\
\hline 90-100 & 8.20 & 0.16 & 0.08 & 23.2 & 0.2 \\
\hline $100-110$ & 8.25 & - & 0.08 & 23.3 & 0.3 \\
\hline
\end{tabular}

2014), with the maximal organic carbon content within the upper $50 \mathrm{~cm}$ followed by a sharp decrease in deeper layers.

The content of $\mathrm{P}_{\text {tot }}$ in both background soils is low in comparison with the anthropogenic soils of the excavation pits. The highest values $(0.21-0.22 \%)$ occur within the litter horizon, while the mineral horizons have a uniform small concentration of phosphorus, which is typical for native soils.

Calcium carbonate content is low (1.6\%) within the upper 40-cm-thick layer and significantly increases in deeper layers, which is also typical for native soils.
The only difference between the background soils 1 and 2 is connected with the presence of the gypsum lens in the former. There is a sharp peak of gypsum content at a depth of $10-20 \mathrm{~cm}$ in this profile, corresponding to the clearly delineated white lens between the darker surface horizon and the humus horizon. Lower down, the gypsum content sharply decreases to almost zero at deeper than $70 \mathrm{~cm}$. At the very bottom of the profile, there is a very small peak of gypsum concentration (50 times smaller than above). 


\subsubsection{Excavation pit IV (residential house)}

The soil has a neutral reaction within its upper part and alkaline within its lower part. A similar $\mathrm{pH}$ distribution pattern is typical for the native soils of the study region and reflects the general trend of downward migration of calcareous soil solutions. The organic matter content is high throughout the soil profile. The maximum amount of organic matter is concentrated within the upper 10-cm-thick layer, which is generally typical for Chernozems.

The $\mathrm{P}_{\text {tot }}$ distribution is irregular. The cultural layers occurring at $0-86 \mathrm{~cm}$ depth are characterized by a high content of total phosphorus (0.26-0.64\%). The buried Chernozem (86-96 cm depth) has a lower $\mathrm{P}_{\text {tot }}$ content, virtually equal to that of the uppermost layer of the modern background soil.

The $\mathrm{CaCO}_{3}$ content is high throughout the profile, being slightly higher in its lower part.

The gypsum content and distribution are very unusual. In the field, at a macromorphological scale, the cultural layers of the excavation pit appeared to be composed of a whitishgrey, ash-like material, relatively homogeneous, compacted, with inclusions of various artefacts. The laboratory analyses have revealed that the cultural layers are composed of a mixture of gypsum and organic matter, with a small amount of calcium carbonate. The data obtained (Table 1) show that a high content of gypsum (more than 49\%) is registered within the cultural layers at depths from 10 to $86 \mathrm{~cm}$, with a gradual downward decrease. The surface layer $(0-10 \mathrm{~cm})$ is relatively impoverished in gypsum $(1.3 \%)$ as a result of leaching.

\subsubsection{Excavation pit III (farm building)}

The excavation pit III contains the remains of a farm building constructed on a single occasion, in contrast to the series of houses in pit IV. This accounts for certain differences in the chemical characteristics as presented below.

The reaction of soil solution is from alkaline at the top to highly alkaline at the bottom of the profile, being generally typical for all the excavation pits within the ancient settlement.

The organic carbon content is characterized by a gradual decrease with depth, unlike the irregular "saw-tooth" distribution pattern in pit IV.

The $\mathrm{P}_{\text {tot }}$ content within the cultural layer is high (more than $0.3 \%$ ). The $60 \mathrm{~cm}$ depth can be considered as a lower border of the cultural layer, with the natural parent rock of the soil occurring below.

The calcium carbonate content is high at the surface $(12.7 \%)$ and clearly increases with depth.

\section{Discussion}

The upper horizons of pits III and IV are the ancient cultural layers (with anthropogenic genesis) according to their morphological characteristics and the archaeological data (Shuteleva et al. 2010). The background soils bear no traces of former human impact.

\subsection{Background soils}

By the content and distribution of $\mathrm{P}_{\text {tot }}$, both background soils adequately reflect its natural background level, which can be used as a reference for separating the natural and anthropogenic layers: the former are poor in phosphorus, while the latter are characterized by a $\mathrm{P}_{\text {tot }}$ content above $0.22-0.23 \%$.

A small amount of calcium carbonate within the uppermost horizon has a biogenic origin, resulting from the calcium carbonate uptake by plant roots and its return to soil upon the roots' death and decay (Afanasyeva 1966; Khokhlova et.al. 2001; Khokhlova, Kouznetsova 2004; Kouznetsova, Khokhlova 2010). This is a general natural phenomenon. A slightly "stretched" $\mathrm{CaCO}_{3}$ distribution pattern can be due to the migration of calcium carbonate solutions in soils under the humid conditions of the region.

The very limited amount of gypsum in background soil 2 is natural for soils formed in humid climates (Khaziev 2007). But the presence of a gypsum lens within the upper part of background soil 1 is very untypical and indicative of secondary salinization. Judging from the low content of gypsum at the bottom of the profile, the salinization could not have developed from below, as a result of groundwater evaporation. The sources of gypsum either came from the surface or from seepage from higher slopes. The latter seems most probable because of the layered texture of the gypsum lens in background soil 1. Similar forms of gypsum occur within the A horizon of background soil 1.

In general, background soil 1 represents a typical anthropogenic profile, with secondary gypsum accumulation being its single distinction from native soils. Most likely, this process is recent and associated with an additional horizontal influx of salts from higher topographic positions with the hummocky microrelief. When dry gypsum gets wet, it swells and increases in volume. Because of the large quantities of gypsum present in the soil, such shrink-swell phenomena lead to the formation of an uneven (hummocky) microrelief. The homogeneous stratum of microcrystalline gypsum is broken by frost cracks, which become major channels for the vertical movement of salt solutions. In summer, when many cracks occlude, the main direction of flow is horizontal, and the lower areas of hummocky microrelief are enriched in gypsum and carbonates.

\subsection{Excavation pit IV}

There is an overall decrease of organic matter content with depth, with occasional humus-rich lenses. These lenses in the upper layers apparently result from manmade depositions of organic matter during the period of settlement building and exploitation and indicate the anthropogenic origin of the cultural layers. Similar lenses in the lower layers, deeper than $86 \mathrm{~cm}$, are a part of the organic matter of the buried paleosol.

The "saw-tooth" pattern of the $\mathrm{P}_{\text {tot }}$ distribution within the total depth of the cultural layers reflects the stages of increase and decrease of anthropogenic pressure during the settlement's period of functioning (Hamond 1983; Holliday, Gartner 2007; Engovatova, Golyeva 2012; Golyeva 
et al. 2014). There is no phosphorus depletion within the upper $10 \mathrm{~cm}$, which is surprising after such a long period (more than 3000 years) following the abandonment of this site. Perhaps the site was later visited by people and/ or another cause of the presence of phosphorus within the surface layer could be its uptake by plants with subsequent decomposition of plant material.

In this excavation pit, the content of calcium carbonate is significantly higher than that in both background soils. The latter are calcareous only at depths more than $50 \mathrm{~cm}$, while the excavation pit profile is calcareous from a depth of $5 \mathrm{~cm}$. Taking into account the relatively high solubility of calcium carbonate, its occurrence in large concentrations at a shallow depth in soils under a percolative water regime is unusual (Khokhlova et al. 2001). However, such large concentrations at a shallow depth are typical for the sites of ancient settlements (Golyeva 2014). They are residues of limestone that was used as house building material. Calcium carbonate forms almost insoluble complexes with phosphates and organic matter (Hamond 1983). That is why even under a percolative water regime the cultural layers of settlements are calcareous.

Comparing the content of gypsum and calcium carbonates revealed a change in the use of bonding agents used in the mud-bricks for house building (Shutileva et al. 2010). The bonding agents were $\mathrm{CaCO}_{3}$-based at the beginning of site occupation and later changed to gypsum. At the final stages of settlement existence gypsum was used with little or no calcium carbonate content.

The present day gradual dissolution of these salts results in the wider distribution of saline solutions beyond the settlement area. The high rainfall of the region causes calcium sulfate swelling, which leads to significant increases in the volume of the gypsum horizon and the further development of the characteristic hummocky microrelief. This microrelief is now observed not only within the settlement area but also far beyond, even in the background soil profile (Figures 2 and 1). Such a microrelief is typical for gypsum deserts (Nettleton et al. 1982; Minashina, Shishov 2002) and absent in the study region, which is within the natural steppe zone.

\subsection{Excavation pit III}

A series of peaks in the organic matter content identified within the cultural layer may be associated with a series of superimposed layers of ruined houses.

In contrast to excavation pit IV, the distribution of phosphorus in excavation pit III is relatively uniform, without any sharp peaks, and in general, with relatively small amounts of phosphorus.

The principal distinctive feature of excavation pit III is an absence of gypsum, which indicates that the former farm building was constructed using only calcium carbonate and without any gypsum.

Because excavation pits III and IV are both located in close proximity to each other, i.e. in similar lithological, geomorphological and climatic conditions and with a common geological and natural history of development, the considerable differences in gypsum content in these pits are uniquely associated with human activity. People brought gypsum from a nearby mine to build their residential houses.

When gypsum-bearing soils become dry, they can become very dense, so after heavy rain the surface run-off is very abundant with little amounts of water absorbed by the local soils. Soils at the bottom of the slope, by the river bank, have become enriched in gypsum and calcium carbonate, despite being far away from the former buildings. These lateral inputs of gypsum and calcium carbonate have resulted in the formation of gypsum and calcareous pedofeatures within the humus horizon of these modern soils.

Gypsum, calcium carbonate and other salts were most likely leached through soils into the groundwater during the period of the settlement building and habitation and later led to severe salinization of the groundwater forcing the inhabitants to abandon the site.

\section{Conclusion}

On the basis of the data obtained it can be confidently concluded that the gypsum-bearing strata in the upper parts of the excavation pits have anthropogenic origin. In other words, people built their houses of mud-bricks made of a mixture of gypsum and organic matter, occasionally with the addition of small amounts of calcareous rocks.

This hypothesis is supported by the differences in gypsum content in excavation pits III and IV. The former is gypsumfree and represents a single-stage farm building, while the latter contains almost pure gypsum within the upper layers and represents a consecutive series of houses built one after another at the same place. The accumulation of large amounts of gypsum rocks within the ancient settlement site resulted in contamination of the environment with gypsum.

The Muradymovo settlement site is located in a humid climatic zone with frequent rainfall, especially in summer. Gypsum solubility in water is relatively high, which causes a gradual deterioration of houses constructed of gypsum and a subsequent contamination of the surrounding areas with gypsum. With a high degree of confidence it can be stated that the abandonment of this area was caused by a humaninduced ecological disaster, i.e. severe salinization of the groundwater, which made it impossible to stay in this area.

During the period of abandonment of this site, the natural processes homogenized the cultural layers of the construction pits. The leaching of salts during the wet seasons was accompanied by the process of upward migration and precipitation of salts during occasional summer droughts as well as severe frosts. Still, the residual amount of gypsum is still large after more than 3000 years following the contamination. Therefore, it can be assumed that the initial man-made soil contamination by gypsum was extremely strong. The properties of the modern soils are being directly affected by the Late Bronze Age human activities, with 3.5 thousand years being an insufficient timescale to restore the soils to be naturally gypsum-free. 
Recently, many more settlements belonging to the "SrubnoAlakul" archaeological culture have been discovered along the Urshak River. We have observed similar cases of gypsum contamination in five sites of these settlements. Therefore, it can be concluded that the extremely negative influence of the Late Bronze Age human activity on modern soils and landscapes has occurred in several locations within this region.

\section{Acknowledgement}

The field work and laboratory analyses were supported by the Russian Science Foundation (projects No. 14-27-00133 and 16-17-10280, respectively). Archaeological excavations were supported by the Russian Humanitarian Fund No. 16-11-02003. We also thank Inga Spiridonova and Michael Hayes for correction of the English language.

\section{References}

AFANASYEVA, E. A. 1966: Chernozems of the Middle Russian Plain. Nauka Press, Moscow.

ANTISARI, L. V., CREMONINI, S., DESANTIS, P., CALASTRI, C., VIANELLO, G. 2013: Chemical characterisation of anthro-technosols from Bronze to Middle Age in Bologna (Italy). Journal of Archaeological Science 40/10, 3660-3671.

ARINUSHKINA, E. V. 1970: Guide on the chemical analysis of soils. Moscow State University Publishing House, Moscow.

2005: Atlas of the Bashkortostan Republic. Ufa Press, Ufa.

BETTIS, E. A. 1988: Pedogensis in Late Prehistoric Indian Mounds, Upper Mississippi Valley. Physical Geography 9/3, 263-279.

BOGOMOLOV, L. V. 1954: Soils of Bashkiria ASSR. USSA Academy of Science Press, Ufa.

BOLAN, N. S., SYERS, J. K., SUMNER, M. E. 1991: Dissolution of various sources of gypsum in aqueous solutions and in soil. Journal of the Science of Food and Agriculture 57, 527-541.

ECKARDT, F. D., DRAKE, N., GOUDIE, A. S., WHITE, K., VILES, H. 2001: The role of playas in pedogenic gypsum crust formation in the Central Namib Desert: a theoretical model. Earth Surface Processes and Landforms 26, 1177-1193.

ENGOVATOVA, A., GOLYEVA, A. 2012: Anthropogenic soils in Yaroslavl (Central Russia): history, development, and landscape reconstruction. Quaternary International 265, 54-62.

GOLDIE, A. S. 2013: The human impact on the natural environment: past, present, and future. John Wiley \& Sons Press.

GOLYEVA, A. 2014: Soil researches on settlement Sosnovka IV (Moscow region). In: Engovatova, A. (Ed.): Archaeology of Moscow Region 10. Institute of Archaeology RAS, Moscow, 64-74.

GOLYEVA, A., ZAZOVSKAIA, E., TUROVA, I. 2016: Properties of ancient deeply transformed man-made soils (cultural layers) and their advances to classification by the example of Early Iron Age sites in Moscow Region. CATENA 137, 605-610.

GORBUNOVA, K. A. 1977: Gypsum karst of the USSR. Geographical Society of the USSR all-union karstology and speleology, Perm University, Perm.

HAMOND, F. W. 1983: Phosphate analysis of archaeological sediments. In: Landscape Archeology in Ireland. BAR British Series 116, Oxford, 47-80.

HOLLIDAY, V. T., GARTNER, W. G. 2007: Methods of soil P analysis in archaeology. Journal of Archaeological Science 34, 301-333.

IUSS Working Group WRB 2014: World Reference base for Soil Resources 2014. International soil classification system for naming soils and creating legends for soil maps. World Soil Resources Reports No 106, FAO, Rome.
JANKOWSKI, M., KITTEL, P. 2012: Evidences of soil-forming processes in red colored Ochre soils (Rubic Arenosols) at the Szynkielew archaeological site, Central Poland. In: Poch, R. M., Casamitjana, M., Francis, L. M. (Eds.): Proceedings $14^{\text {th }}$ International Working Meeting on Soil Micromorphology. Lleida-Spain 8-14 July 2012. Lleida, 40-42.

KHAZIEV, F. K. 2007: The soil of the Republic of Bashkortostan and the regulation of their fertility. Gilem, Ufa.

KHOKHLOVA, O. S., KOUZNETSOVA, A. M. 2004: Carbonate accumulation morphology in a soil chronosequence in the southern Pre-Ural, Russia: Significance for Holocene paleoenvironmental reconstruction. Revista mexicana de ciencias geológicas 21/1, 185-194.

KHOKHLOVA, O. S., KOVALEVSKAYA, I. S., OLEYNIK, S. A. 2001: Records of climatic changes in the carbonate profiles of Russian Chernozems. CATENA 43/3, 203-215.

KUZNETSOVA, A. M., KHOKHLOVA, O. S. 2010: Morphology of carbonate accumulations in soils of various types. Lithology and mineral resources 45/1, 89-100.

LIMA, H. N., SCHAEFER, C. E. R., MELLO, J. W. V., GILKES, R. J., KER, J. C. 2002: Pedogenesis and pre-Colombian land use of "Terra Preta Anthrosols" ("Indian black earth") of Western Amazonia. Geoderma 110/1-2, 1-17.

MARKIEWICZ, M., BEDNAREK, R., JANKOWSKI, M., ŚWITONIAK, M. 2013: "Paleotechnosols" of ancient settlements in Grodno and Kałdus. In: Charzyński, P., Hulisz, P., Bednarek, R. (Eds.): Technogenic soils of Poland. Polish Society of Soil Science, 111-121.

MINASHINA, N. G., SHISHOV, L. L. 2002: Gypsum-Containing Soils: Their Distribution, Genesis, and Classification. Eurasian Soil Science $35 / 3,240-249$

Nettleton, W. D., Nelson, R. E., BRASHER, B. R., DERR, P. S. 1982: Gypsiferous soils in the western United States. In: Kittrick, J. A., Fanning, D. S., Hossner, L. R. (Eds.): Acid Sulfate Weathering. Soil Science Society of America Special Publication 10, 147-168.

NICOSIA C., BALISTA C., CUPITÒ M., ERTANI A., LEONARDI G., NARDI S., VIDALE M. 2011: Anthropogenic deposits from the Bronze Age site of Fondo Paviani (Verona, Italy): Pedochemical and micropedological characteristics. Quaternary International 243, 280-292.

OBYDENNOVA, G. T., SHCHERBAKOV, N. B., SHUTELEVA, I. A., KHOKHLOVA, O. S., KOVALJUH, N. N., SKRIPIN, V. V. 2008: Results of the application of a complex approach in studying a monument of a Late Bronze Age at Muradymovo in Bashkortostan. In: Works of II (XVIII) All-Russian Archaeological Congress in Suzdal. Moscow. 435-438.

PAWŁOWSKI, D., MILECKA, K., KITTEL, P., WOSZCZYK, M., SPYCHALSKI, W. 2015: Palaeoecological record of natural changes and human impact in a small river valley in Central Poland. Quaternary International 370, 12-28.

REDMAN, C. L. 1999: Human impact on ancient environments. University of Arizona Press.

ROSEN, M. R., WARREN, J. K. 1990: The origin and significance of groundwater-seepage gypsum from Bristol Dry Lake, California, USA. Sedimentology 37, 983-996.

SÁNCHEZ-PÉREZ, S., SOLLEIRO-REBOLLEDO, E., SEDOV, S., MCCLUNG DE TAPIA, E., GOLYEVA, A., PRADO, B., IBARRAMORALES, E. 2013: The Black San Pablo Paleosol of the Teotihuacan Valley, Mexico: Pedogenesis, Fertility, and Use in Ancient Agricultural and Urban Systems. Geoarchaeology 28/3, 249-267.

SHCHERBAKOV, N. B., LEONOVA, T. A., SHUTELEVA, I. A., GOLYEVA, A. A. 2015: Anthropogenetic factor of landscape change in the process of early urbanization on the territory of Southern Transurals. In: Conference on the Environmental Archaeology of European Cities. $80-81$

SHCHERBAKOV, N. B., SHUTELEVA, I. A., LEONOVA, T. A., GOLEVA, A. A., LUNKOVA, Y. V, KRAEVA, L. A. 2013: The ceramic complex as reflection of intercultural exchange of the Late Bronze Age tribes of the Southern Transurals. In: Creativity: an exploration through the Bronze Age and contemporary responses to the Bronze Age. University of Cambridge. 32-33.

SHUTELEVA I. A., SHCHERBAKOV N. B., BALONOVA M. G., KHOKHLOVA O. S., GOLEVA, A. A. 2010: Some results of the application of a complex approach to the research of the Late Bronze 
age settlement the Volgo-Ural region. Interdisciplinaria Archaeologica, Natural Sciences in Archaeology I/1-2/2010, 29-36.

SLAVNYI, Y. A. 2003: Halogenesis in soils of the lower Volga region. Eurasian Soil Science 36/1, 1-10.

THY, P., WILlCOX, G., BARFOD, G. H., FUller, D. Q. 2015: Anthropogenic origin of siliceous scoria droplets from Pleistocene and Holocene archaeological sites in northern Syria. Journal of Archaeological Science 54, 193-209.

VOROBIOVA, L. A. 1998: Chemical analysis of soils. Moscow State University Publishing House, Moscow.

VOROBIOVA, L. A. 2006: Theory and practice of the chemical analysis of soils. GEOS Publishers, Moscow.

VRYDAGHS, L., DEVOS, Y. 2007: Contribution of Archaeopedology to the palaeoenvironmental reconstruction of (pre-)urban sites at Brussels (Belgium). Atti della Società Toscana de Scienze Naturali di Pisa, Serie A, 112, 145-151.
WARREN, J. K. 2006: Evaporites: Sediments, Resources and Hydrocarbons. Springer, Berlin.

WATSON, A. 1985: Structure, chemistry and origins of gypsum crusts in southern Tunisia and the central Namib Desert. Sedimentology 32, $855-875$.

WEISS T. J., COURTY M.-A. 1993: The genesis and collapse of third millennium North Mesopotamia civilization. Science 261, 995-1004.

WOODS, W. I., MCCANN, J. M. 1999: The anthropogenic origin and persistence of Amazonian dark earths. Conference of Latin Americanist Geographers Yearbook 25, 7-14.

ZIELIŃSKI, P., SOKOŁOWSKI, R., FEDOROWICZ, S., JANKOWSKI, M. 2011: Stratigraphic position of fluvial and aeolian deposits in the Żabinko site (W Poland) based on TL dating. Geochronometria 38/1, 64-71. 